\title{
palgraveroivot
}

\section{Comics, the Holocaust and Hiroshima}

$\bullet \bullet \bullet \bullet \bullet \bullet \bullet \bullet \bullet \bullet \bullet \bullet \bullet \bullet \bullet \bullet \bullet \bullet \bullet \bullet \bullet \bullet \bullet \bullet \bullet \bullet \bullet \bullet \bullet \bullet \bullet \bullet \bullet \bullet \bullet \bullet \bullet \bullet \bullet \bullet \bullet \bullet \bullet \bullet \bullet \bullet \bullet \bullet \bullet \bullet \bullet \bullet \bullet \bullet \bullet \bullet$ Comics, the Holocaust and Hiroshima breaks new ground by arguing that comics have a dual role as sources of cataclysm between 1939 and 1945. First for historians to gauge awareness of the Holocaust and second through close analysis, of Paroles d'Etoiles in Vichy France and Barefoot Gen in Hiroshima, as testimonies of childhood emotions, experiences and memories. Calling for an extension of the range of source material relating to persecution, genocide and the atomic bomb from 1939 to 1945 , comics are posited as an agent to build on the scholarship of new cultural history, historiography, memory and trauma studies. These fields connect through the shared ground of cultural record, which can be either deliberate/explicit or incidental reference. The comics form is a flexible one with potential to explore the space between reality and representation, with visuals working as iconic translations while narrative structure relies on readers' mental contribution.

\section{Authors:}

Jane L. Chapman is Professor of Communications at the University of Lincoln, Research Associate Wolfson College, Cambridge, UK and the author of ten books. She is Principal Investigator for the Arts and Humanities Council's 'Comics and the World Wars - a Cultural Record' project, for which Dan Ellin and Adam Sherif are researchers, and is an AHRC grant holder for two other projects on World War One.

Dan Ellin is Research Assistant for the AHRC funded 'Comics and World Wars' project at the University of Lincoln, UK. A student at the University of Warwick, his research examines the lives and emotions of RAF ground personnel during the Second World War.

Adam Sherif is Researcher on the Arts and Humanities Council's 'Comics and the World Wars' project at the University of Lincoln, UK and is co-authoring a book of the same name. He is also a contemporary comics critic.

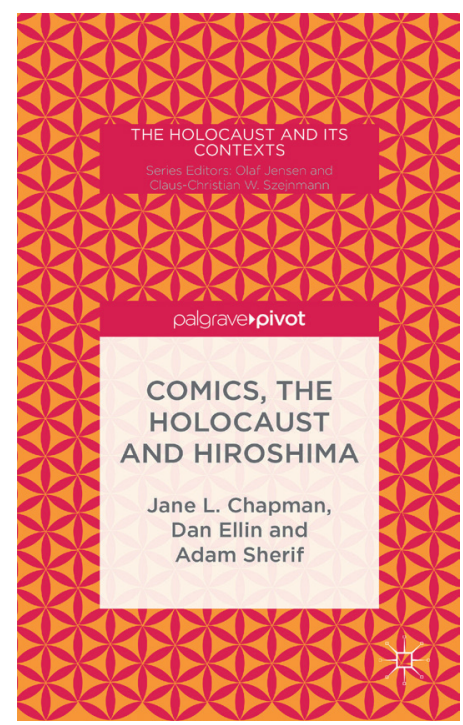

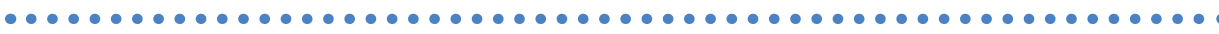

Contents:

1. Introduction

2. Case study: National Socialist Persecution and Genocide in

Contemporary US Comic Books

3. Childhood Memories of the Holocaust and Vichy

4. Barefoot Gen and Hiroshima: Comic Strip Narratives of Trauma

5. Conclusion

•................

eBook pub details:

ePub 9781137407245| Jun 2015 | £30.00 | \$45.00

PDF 9781137407252 | Jun $2015|£ 30.00| \$ 45.00$

Hardcover 9781137407238 | Apr 2015 | $£ 45.00$ | Discounted Price $£ 31.50$

| \$67.50 | Discounted Price \$47.25

\section{0\% off with promo code PM15THIRTY valid until 30th October 2015}

This price is available to individuals only. This offer is not available to our trade and library customers. Offer only valid outside of Canada and Australasia and valid only on Hardcover copies. Orders must be placed direct with Palgrave Macmillan.

To order your copy at this special price, visit www.palgrave.com or email your order to orders@palgrave.com (for UK and ROW) or sales@palgrave-usa.com (for USA) and quote the above promo code.

Publishing peer-reviewed, mid-length research across the Humanities, Social Sciences and Business, within 12 weeks of acceptance. 